\title{
4. Gazprom Neft: reformed rake
}

Gazprom Neft is the oil arm of Gazprom, which is the world's largest gas company by any measure. Gazprom Neft was created on the basis of the oil company Sibneft, which was owned by the Russian oligarch Roman Abramovich, who sold it to Gazprom for a handsome price. The acquisition of Sibneft facilitated Gazprom's foray into the oil industry. A key question is whether the former Sibneft has managed to retain its unique identity, culture and strategy or has come to function more like a department of Gazprom.

Although Gazprom Neft is now a Gazprom subsidiary, it is also a major corporation in its own right and the country's third-largest oil producer and third-largest oil refiner. It is also the only company that produces significant amounts of oil on Russia's Arctic continental shelf, from the Prirazlomnoye field in the Pechora Sea.

With $95.68 \%$ of the shares, Gazprom fully controls Gazprom Neft; the remaining shares are traded on the open market (Gazprom Neft 2017c). Gazprom Neft's headquarters are in Saint Petersburg, the city to which Gazprom proper is also moving from Moscow.

The general directorship of Sibneft and then Gazprom Neft has been fluid. Abramovich was unwilling to take up the post of general director of Sibneft, although he ran the company to all intents and purposes. Sibneft had three different general directors in its first five years from 1995 to 2000; then the directorship changed twice again after Gazprom acquired Sibneft in 2005.

In 2017, Gazprom Neft surpassed Surgutneftegas and for the first time became the third-largest oil producer in Russia (Gazprom Neft 2017a). In 2018 , its production of hydrocarbons increased by $3.5 \%$ from the 2017 level to 92.9 million tonnes of oil equivalent. Taking into account Gazprom Neft's shares in joint ventures, as of December 2018 its total reserves of hydrocarbons under the international 2P category (proved +probable) amounted to 2.84 billion tonnes of oil equivalent (Gazprom Neft 2018r).

Gazprom Neft oversees over 70 oil-producing, refining and marketing organizations in Russia, the former Soviet Union and other countries. It holds $50 \%$ stakes in several affiliated companies, namely Slavneft, Tomskneft, Salym Petroleum Development, Messoyakhaneftegaz, Northgaz and SeverEnergiya (Gazprom Neft 2017b). Its upstream operations are concentrated in Khanty-Mansi and Yamal-Nenets Autonomous Districts and Tomsk, Omsk and Orenburg regions. Its main refining facilities are located in Moscow, 
Omsk, Yaroslavl, Belarus and Serbia. Gazprom Neft conducts exploration and production activities in Angola, Bosnia and Herzegovina, Hungary, Iraq, Romania, Serbia and Venezuela. Its network of fuel stations comprises 1859 units in Russia, the Commonwealth of Independent States (CIS) and Europe.

\section{CORPORATE HISTORY}

\section{The 1990s: The Oligarchs' Playground}

Sibneft was founded by special Presidential Decree 872 of 24 August 1995, on the basis of some of Rosneft's most precious assets. This contrasts with other Russian oil companies, which were established by standard government orders. At the time, Sibneft included Noyabrskneftegaz, the 22-million-tonne oil producer located in the Yamal-Nenets Autonomous District, the Omsk refinery, one of the largest and most modern in Russia, and the exploration company Noyabrskgeofisika and Omsknefteprodukt, an oil product distribution company. Investment analysts commented at the time that 'Sibneft has only four subsidiaries, but they are all top class' (Salomon Brothers 1996, p. 86).

Noyabrskneftegaz was, in effect, one of the youngest oil producers in Western Siberia, with a relatively low water-cut in its reservoirs, low field depletion rates and a high daily output from its wells. In the mid-1990s, despite financial difficulties, Noyabrskneftegaz was the only Russian oil company that managed to replace its reserves through exploration drilling. Moreover, Noyabrskneftegaz was fortunate to have reserves of sweet and light oil, which could be supplied as Siberian Light blend and guaranteed high-quality refined products (TRINFICO 1996).

The creation of Sibneft involved a scandal. Setting up the company required the support of two powerful businessmen who controlled key assets, Victor Gorodilov, the General Director of Noyabrskneftegaz, and Ivan Litskevich, who was the General Director of the Omsk refinery and a well-known advocate of the interests of the Omsk region. While Gorodilov supported the establishment of Sibneft, Litskevich opposed it. Decree 872 was signed only days after Ivan Litskevich had drowned while swimming in a river (TRINFICO 1996).

In 1995, Victor Gorodilov became the first General Director of Sibneft. Gorodilov was replaced in 1997 by Andrei Blokh, who had previously worked as the Deputy Director of Ecogazmotor and Deputy General Director of Petroltrans (two small, low-profile companies). Gorodilov's son Andrei Gorodilov continued to work in Sibneft for several years. Blokh was replaced two years later by Evgeniy Shvidler, a long-time business acquaintance of Abramovich and his partner in the oil-trading venture Runicom. Shvidler had 
joined Sibneft at the outset as Senior Vice President. He served as General Director until Sibneft's acquisition by Gazprom in 2005 (Knyazev 2010).

Sibneft has a murky past, and its history is closely connected with two of the most famous oligarchs of the post-Soviet period: Boris Berezovskiy and Roman Abramovich (Lysova 2005). The 'trial of the century' in the High Court of London in 2011 (see below) threw new light on what happened in the 1990s. It confirmed that Sibneft was bought under a corrupt scheme, as was the case with most Russian business in the 1990s. Boris Berezovskiy filed a lawsuit against Roman Abramovich in 2007 demanding USD 5.5 billion in compensation for damages that he claimed he suffered when he sold his stakes in Sibneft and Rusal, allegedly below the market value and under pressure and threats from Roman Abramovich. During the trial, it was revealed that in 1995 Boris Berezovskiy had convinced Boris Yeltsin to establish Sibneft and privatize it in such a way that Roman Abramovich would end up owning the company. Some experts suggest that Sibneft was expected to sponsor the ORT TV channel that Berezovskiy controlled then and that would have supported Yeltsin during the 1996 presidential elections (Zanina 2011).

In fact, Yeltsin ensured that Sibneft was privatized in phases; the bulk of the government stake was sold through the loans-for-shares auction. In December 1995, Neftyanaya Finansovaya Kompaniya (NFK), controlled by Boris Berezovskiy and Roman Abramovich, bought a 51\% stake in Sibneft that was held by the government, paying USD 100 million (Neft i kapital 2004a). In January 1996, another block of shares (14.28\%) was auctioned off, and it was understood that NFK was again the buyer (Rozhkova and Reznik 2009). In September and October 1996, 19\% and 15\% were sold at investment tenders for USD 45 million and USD 35.5 million, respectively. Finally, in December 1996, a $0.72 \%$ stake was sold at an auction. All these stakes were acquired by companies controlled by Abramovich and Berezovskiy (Rozhkova and Reznik 2009).

Ultimately, the Abramovich-Berezovskiy team gained control of $90 \%$ of Sibneft. However, the ownership structure of Sibneft was never transparent. When Sibneft was privatized, Abramovich was not even mentioned: Berezovskiy was considered to be the buyer of the company. It was only in December 1999 that Abramovich admitted in an interview with the business newspaper Vedomosti that he was the co-owner of Sibneft (Rozhkova and Reznik 2009). In 2011, Abramovich stated in the High Court of London that the rumours that Berezovskiy was a shareholder of Sibneft actually helped the company, given the political influence of Boris Berezovskiy at the time (Forbes 2011). Ultimately Abramovich won the lawsuit in London.

At the very beginning, in a foretaste of things to come much later, Sibneft was linked to Gazprom. In December 1996, Rem Vyakhirev, Head of the gas monopoly, was appointed chairman of Sibneft's board of directors; however, 
in September 1997, he declined re-election to the board because of his heavy workload at Gazprom (Neftegaz 1999).

Sibneft made its first attempt to merge with YUKOS in 1998; however, the resulting Yuksi 'super-company' existed for only six months. Experts widely blamed the psychological incompatibility of the individuals behind the two corporations (Berezovskiy, Abramovich and Mikhail Khodorkovskiy) for the failure of the merger (Neft i kapital 2004b).

In the second half of the 1990s, Sibneft was considered to be the most likely candidate to purchase Rosneft, which was slated for privatization (see the chapter on Rosneft). However, Sibneft's ambitions did not materialize, mainly because the privatization of Rosneft was postponed indefinitely.

In 1998, Sibneft was the third Russian oil company after LUKOIL and Surgutneftegas to consolidate shares as it began to swap shares in its subsidiaries for shares of the Sibneft holding. Sibneft used a unique approach to these share swaps: instead of the usually complicated process, the holding simply wrote letters to the shareholders of Noyabrskneftegaz and Noyabrskgeofizika offering to exchange shares with them. Analysts subsequently concluded that the proposed swap ratios were fair and justified (Savushkin 1998).

Sibneft was the first Russian oil company to issue Eurobonds (in September 1997, these were worth USD 150 million). It was also the first to publish consolidated financial statements under generally accepted accounting principles (GAAP) and conduct an international reserve audit (Neft i kapital 2004c). In 1997, the trade of Sibneft's shares began in the Russian Trading System (RTS), and in 1999, the company issued Level-I American depository receipts (ADRs), which were traded in the United States as well as on the Berlin and Frankfurt stock exchanges.

In the late 1990s, Elf Aquitaine sought to buy 5\% of Yuksi; however, after the collapse of Yuksi, negotiations shifted to the purchase of some 12\% of Sibneft. However, in September 1998, as the financial crisis hit and the oil price plummeted, Elf Aquitaine abandoned all its plans (Vinogradov 1998).

\section{0-05: The Rake's Progress}

In the early 2000s, during the prolonged period of rising oil prices, Sibneft and YUKOS drove crude production growth in Russia. Sibneft was the favourite of investors because of its record high growth rates combined with low capital and operating costs. In 2001, its oil output grew by $20 \%$, and in 2002 and 2003 , it increased by $27 \%$ and $19 \%$, respectively, while its lifting costs were only USD 1.7-1.8 per barrel (cf. USD 2.8-3 for LUKOIL and Tyumen Oil Company (TNK)). Sibneft was fortunate to have excellent reserves, particularly in terms of the high average daily output of wells (Figure 4.1). At the same time, its share of idle wells was over $50 \%$ in 2002. 
Both Sibneft and YUKOS intensified production through the aggressive use of hydrofracking ${ }^{1}$ and horizontal drilling, which they performed with the help of Schlumberger and Halliburton. Sibneft and YUKOS made significant investments in production, which were recouped through the rapid growth of oil output. Similarly to YUKOS, Sibneft introduced a new strategy focused on maximizing the current profitability of oil extraction with the ultimate goal of increasing the market value of the company (Neft i kapital 2004d). Sibneft and YUKOS were both strongly criticized for having applied enhanced oil recovery methods at the early stages of field development and for skimming the oilfields, since these approaches could allegedly damage reservoirs in the long term (Neft i kapital 2004d).

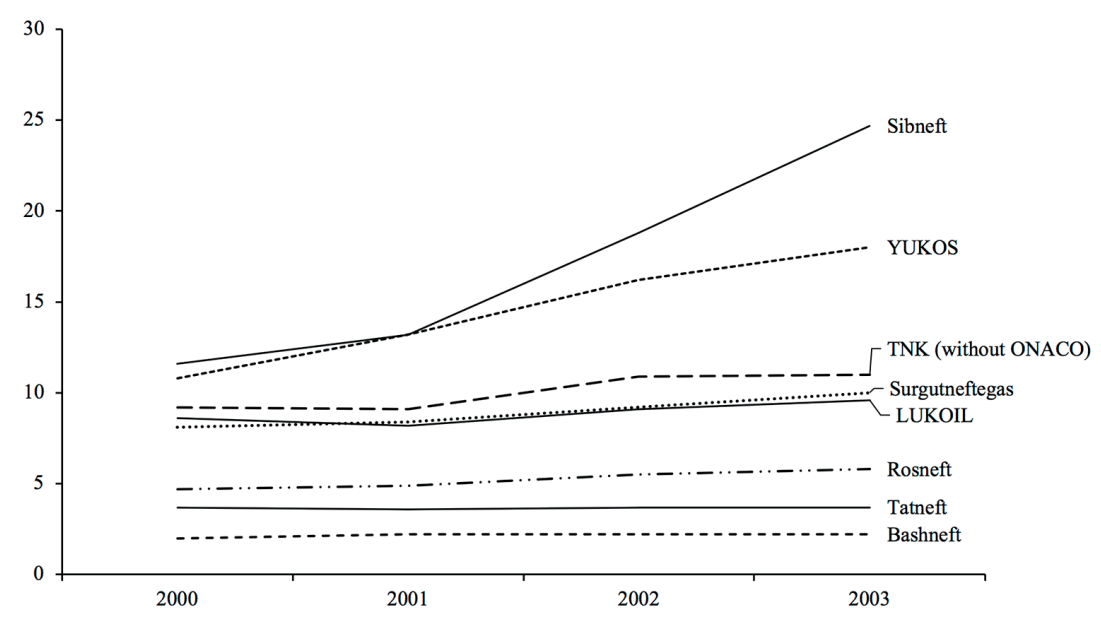

Figure 4.1 Average daily output of operating wells of companies (tonnes/day), 2000-03

Note: Rosneft (2003) without Severnaya Neft. Source: Neft i kapital (2004d).

Other factors in Sibneft's growth included the commissioning of the major field Sugmutskoye in the Noyabrsk area of Yamal-Nenets Autonomous District in 2000 as well as the acquisitions that expanded the geography of its operations. In 2001, Sibneft and Chukotka Trading Company established Sibneft-Chukotka on a 50:50 basis. Chukotka Trading Company contributed to the authorized capital licences for the development of several fields (Lagunnoye, Telekaiskoye and Zapadno-Ozernoye). In 2004, Sibneft produced the first oil in Chukotka (Neft, gaz i fondovyy rynok 2008). 
In December 2002, Sibneft bought $10.83 \%$ of Slavneft from Belarus for USD 207 million. Soon afterwards, an auction was held for the $74.95 \%$ of Slavneft owned by the Russian state. The winner was Investoil, created by Sibneft and TNK on a 50:50 basis. They paid USD 1.86 billion. A further $12.98 \%$ of Slavneft was already held by a trust company controlled by Sibneft and TNK (Neft, gaz i fondovyy rynok 2008). The new owners wanted to divide Slavneft; however, as they could not reach an agreement on the division or on whether one of the partners should buy out the other, they decided to divide Slavneft's oil, petroleum products and financial flows (Egorova 2006a).

During the early 2000s, Sibneft greatly strengthened its marketing arm mainly because it was considered a weakness that it had Omsknefteproduct as its sole petroleum product distributor. Thus, in 2000, Sibneft purchased a controlling interest in two product distribution companies in the Ural region, which enabled it to establish a strong foothold there. In 2001, it bought 78.4\% of Tyumennefteproduct from TNK. In 2002 and 2003, Sibneft established oil product distribution subsidiaries in Krasnoyarsk and Saint Petersburg in order to develop its marketing networks in those regions (Neft, gaz i fondovyy rynok 2008).

During the 2000s, Sibneft fully demonstrated its traditional ability to turn conflicts over asset acquisition to its advantage. When ONACO - an 8-million-tonne-per-annum producer based in Orenburg - was to be privatized in 2000, a serious dispute arose between Sibneft and TNK over its assets. Sibneft joined forces with YUKOS and Stroitransgaz and began leading the alliance. It also bought $38 \%$ of ONACO's subsidiary, Orenburgneft, from YUKOS for USD 430 million in 2000. The starting price of the $85 \%$ state stake in ONACO was USD 425 million. During a lengthy round of bidding, the Sibneft-YUKOS-Stroitransgaz alliance offered USD 1 billion. TNK bid an additional USD 80 million and won. However, TNK was unhappy that Sibneft held $38 \%$ of Orenburgneft and began to negotiate with its rival to convince it to either sell or swap this stake. No agreement was reached until spring 2003 when Sibneft sold 38\% of Orenburgneft and 1\% of ONACO (which it had bought on the secondary market) to TNK for USD 825 million. By doing this, Sibneft made an impressive profit in a short space of time (Neft i kapital 2004e).

In the early 2000s, Sibneft consistently optimized tax payments through various schemes, resulting in one of the lowest profit tax rates in the sector. For instance, according to Sibneft's US GAAP statements, in 2003, it only paid $7 \%$ tax compared to the official Russian business rate of $35 \%$. In February 2004, during the YUKOS case, the Ministry of Taxes and Duties made fiscal claims for the period 2000-01 against Sibneft amounting to USD 1 billion. The company reached a compromise by paying some USD 300 million to the state (NEWSru 2004). However, while saving on taxes, Sibneft always 
remained generous to its shareholders. In 2001, it paid over USD 1 billion in dividends, and in 2001, it paid USD 1 billion. In 2003, it paid no dividends because of its split from YUKOS; however, in 2004, the dividend payments amounted to USD 2.3 billion (Borisov 2005). According to some analysts, the shareholders pumped money out of Sibneft on the eve of its sale to Gazprom in 2005 (Egorova 2006b).

Sibneft has been involved in several high-profile corporate disputes, with the most infamous one being over the control of the Moscow refinery. In 2001, the Moscow city authorities had merged the refinery with Cyprus-based Sibir Energy, which was established by Shalva Chigirinskiy and his partner Igor Kesayev to create a vertically integrated company - the Moscow Oil and Gas Company (69\% Moscow authorities; 31\% Sibir Energy). Sibneft bought a block of the refinery shares from LUKOIL in 2001 (see the chapter on LUKOIL). In 2002, Sibneft and Tatneft, a fellow shareholder, launched a corporate war against the Moscow city authorities and Sibir Energy for the control of the assets. During the corporate hostilities, which lasted six years, the parties established parallel managing bodies and blocked oil deliveries to the refinery through court decisions. When Gazprom took over Sibneft in 2005, it sought to resolve the issue. However, in June 2006, representatives of Gazprom Neft were not admitted to the annual general meeting of the Moscow refinery, supposedly because of some technicalities related to the letter of authorization (Reznik and Tutushkin 2006). In 2007, peaceful negotiations began and in 2008 the shareholders agreed on the joint management of the refinery. The parties to the conflict signed a memorandum on cooperation pledging that they would manage the refinery on a parity basis; henceforth, representatives of Gazprom Neft joined the managing board of the Moscow refinery (Tutushkin 2008a).

Another controversy, also with Sibir Energy, broke out over Sibneft-Yugra, which had been established in 2000 on a 50:50 basis by Sibir Energy and Sibneft. Sibir Energy contributed $99.34 \%$ of Yugraneft to the joint venture, including its three oilfields in Khanty-Mansi Autonomous District. Sibneft became the operator of the joint venture with the obligation to provide funds for the development of the fields. In 2004, Sibir Energy's management discovered that Sibneft had diluted the stake of Sibir Energy in Sibneft-Yugra from $50 \%$ to $1 \%$ through two additional issues of shares approved at shareholder meetings. Sibir Energy stated that its stake in Yugraneft had been diluted without its permission and began to fight for the return of the asset. For its part, Sibneft claimed that all transactions had the approval of Sibir Energy's main shareholders (Tutushkin 2005). The court battles between Sibneft and Sibir Energy went on for a long time without a clear result (Reznik and Derbilova 2005a). 
Yet another scandal with far-reaching political implications surrounded the second merger attempt of Sibneft and YUKOS in spring 2003. The resulting company would have been Russia's largest in terms of oil production and reserves and the world's second-largest private oil producer. Neither company denied that a significant stake in the new venture would eventually be offered to a foreign investor (Lenta.ru 2003). It was expected that Mikhail Khodorkovskiy would lead the company, while Evgeniy Schvidler would be the chairman of the board of directors. The representatives from YUKOS and Sibneft indicated that they had received political approval for the transaction (Landes and Nagaria 2003). By October 2003, YUKOS had obtained some $92 \%$ of Sibneft's shares, providing in return USD 3 billion and $26 \%$ of its own shares. However, soon after the deal was closed, Mikhail Khodorkovskiy was arrested. Millhouse Capital - a UK-registered company, established in 2001 to manage Roman Abramovich's assets and led by Evgeniy Shvidler - demanded the termination of the transaction. After lengthy court battles, Millhouse recovered 57.5\% of Sibneft's shares in October 2004 and another 14.5\% in July 2005. By September 2004, YUKOS learned that Abramovich did not intend to return the USD 3 billion and decided to initiate a lawsuit against Millhouse in the London Court of International Arbitration. In 2006, YUKOS was declared bankrupt by the government, and its bankruptcy manager, appointed by the Russian government, reached an amicable settlement with Millhouse concerning this lawsuit (Surzhenko and Reznik 2006).

\section{5 to the Present: Reform of the Rake, Life under Gazprom's Tutelage}

A new stage in the life of Sibneft began after it was acquired by Gazprom. In September 2005, Gazprom and Millhouse Capital signed an agreement on the purchase of $72.6 \%$ of Sibneft for USD 13 billion. Earlier, Gazprom had bought $3.016 \%$ of the company that was held by Gazprombank (RBC 2005), culminating in a $75.6 \%$ share. YUKOS owned $20 \%$ of the company, and this block was acquired along with its other assets (Derbilova 2005).

Alexander Ryazanov, the deputy chairman of Gazprom's managing board, was appointed Sibneft's Head, replacing Evgeniy Shvidler (Reznik and Derbilova 2005b). Ryazanov admitted in an interview with Vedomosti that Gazprom had overpaid for Sibneft, allowing its former shareholders to skim the cream off the transaction (Reznik 2006c). German Gref, who was a member of Gazprom's board of directors at the time, was categorically against the deal because he was sure that the purchase price was inflated. Ultimately, however, he gave in and Abramovich became the richest Russian in 2005, according to Forbes (Rozhkova and Reznik 2009).

Gazprom soon discovered that its new asset had unexpected flaws. First, its reserves turned out to be smaller than anticipated. Petroleum consultants 
De Golyer \& MacNaughton concluded that by the end of 2005, Sibneft's total liquid reserves had decreased by $17 \%$, while proved and producing reserves had declined by $46 \%$ (as compared to the results of an audit by Miller and Lents at the beginning of 2005). However, by 2006, proved and producing gas reserves had subsequently doubled (Reznik 2006d). Second, in 2005, Sibneft's oil production decreased for the first time in many years from 34 million tonnes per annum to 33 million tonnes per annum (Neftegazovaya vertikal 2006a). In 2006, it was expected that given the current level of investments, by 2010 its oil output could shrink to around 17 million tonnes (without taking into account Sibneft-Yugra and Sibneft's stake in Slavneft). Valeriy Nesterov, from the private investment bank Troika Dialog, concluded that the former owners had artificially inflated the company's value before its sale. Other analysts noted that Sibneft conducted the exploration and development of new fields without due care and attention and that the extraordinary rates of production growth achieved through aggressive hydrofracking were unsustainable. At the same time, Sibneft's extraction costs rose to USD 2.44 per barrel and were expected to continue growing (Reznik 2006a). They reached a record high level of USD 5.86 per barrel in 2008, making Sibneft's extraction costs some of the highest among Russian oil companies (Mazneva 2010a).

On 29 March 2006, Sibneft's board of directors decided to rename the company Gazprom Neft, and they re-registered it in Saint Petersburg (Reznik and Temkin 2006). Gazprom could not decide for a whole year what to do with its new asset. The monopoly's leading figures had divergent views on whether to leave the oil subsidiary as an independent company or incorporate it fully into the structure of Gazprom (Reznik 2006b). In September 2006, they decided that Gazprom Neft should remain a separate business unit within Gazprom, responsible for the development of its oilfields and the oil fringes of its gas fields (Tutushkin 2007).

In November 2006, Alexander Ryazanov was unexpectedly dismissed from his positions both in Gazprom and Gazprom Neft, despite his achievements as the Director of Gazprom Neft. Under his leadership, the company had stabilized oil production through large investments. Ryazanov had arranged for smaller dividends to be paid to shareholders and had allocated more funds for development. He insisted on transferring the Prirazlomnoye oilfield in the Pechora Sea from a Gazprom subsidiary to Gazprom Neft and arranged for the produced oil to be exported via an oil trader rather than Gazpromexport. Ryazanov's efforts to increase Gazprom Neft's independence might have annoyed two influential deputy chairmen of Gazprom: Alexander Medvedev, who insisted on Gazprom having a single export channel for all its production, and Alexander Ananenkov, who lobbied for the complete integration of the company into Gazprom's structure. Also, Ryazanov promoted Gazprom's purchase of a $20 \%$ stake of Sibneft from YUKOS. However, Rosneft coveted 
this $20 \%$ stake. Some experts believed that Ryazanov might have thus become a headache for the chairman of Rosneft's board of directors Igor Sechin (Neftegazovaya vertikal 2006b).

Alexander Dyukov, the President of petrochemicals company Sibur Holding and an old-time acquaintance of the chairman of Gazprom's management committee Alexei Miller, was appointed CEO of Gazprom Neft, replacing Ryazanov (Malkova and Reznik 2006). In April 2007, during the sale of YUKOS assets, the joint venture Enineftegaz, established by Gazprom, ENI and Enel, bought 20\% of Gazprom Neft and some gas subsidiaries of YUKOS (Mazneva 2007).

Another scandal erupted during the sale of YUKOS' oil assets, which mostly concerned Rosneft (see the chapter on Rosneft). In May 2007, a Rosneft subsidiary bought several assets from YUKOS, including Tomskneft. Rosneft then announced that it would sell a 50\% stake in Tomskneft to Vnesheconombank (reportedly working on behalf of Gazprom Neft). When Rosneft stated that the deal was closed, Vnesheconombank denied this (Petrachkova and Derbilova 2007). However, the scandal was hushed up, and in December 2007, Gazprom Neft directly acquired half of Tomskneft for USD 3.6 billion (Malkova and Mazneva 2007).

In the best traditions of Sibneft, Gazprom Neft continued to grow through acquisitions. In 2009, in fierce competition with TNK-BP, Gazprom Neft bought $16 \%$ of Sibir Energy, which permitted Gazprom Neft to consolidate $52 \%$ of the Moscow refinery indirectly. Gazprom Neft was also interested in Sibir Energy's participation in the Salym Petroleum Development - a joint venture with Shell created in 1996, which produced some 8 million tonnes of oil per annum (Baraulina et al. 2009). Gradually, Gazprom Neft increased its share in Sibir Energy to 80.37\%, having spent USD 2.4 billion in total for this acquisition (Mazneva 2010b). In February 2011, the ten-year dispute over Sibir Energy and the Moscow refinery (see above) eventually ended, and Gazprom Neft became the sole owner of Sibir Energy (Mazneva 2011).

In February 2010, Gazprom Neft bought STS-Service, an oil production subsidiary of the Swedish Malka Oil, which operated in the Tomsk region. In January 2011, Gazprom Neft and TNK-BP bought the Messoyakha project from Slavneft and established a 50:50 joint venture - Messoyakha Neftegaz - to develop the Messoyakha group of fields in northern Yamal, with Gazprom Neft as the project operator (Gavshina 2011). In 2011, Gazprom Neft created a new cluster of liquid hydrocarbons production under Gazprom Neft-Orenburg, which was developing oil reserves in the eastern part of the Orenburg oil, gas and condensate field. It also received licences for the Tsarichanskaya and Kapitonovskaya group of fields located close to the Orenburg field. As a result, between 2011 and 2017, Gazprom Neft's 
production in the Orenburg region grew from 0.4 to 4.8 million tonnes of oil equivalent (Gazprom Neft 2018o).

During the same period, in addition to the acquisitions, Gazprom Neft brought on stream several important assets. For example, in 2012, the first phase of the Samburgskoye oil, gas and condensate field was commissioned. This field belongs to the Russian-Italian SeverEnergiya in which Gazprom Neft holds a 25\% stake. In December 2013, Gazprom Neft - as the operator of the Prirazlomnoye field in the Pechora Sea - produced Russia's first Arctic offshore oil. To date, it continues to be the only Russian oil company that actually produces hydrocarbons offshore in the Russian Arctic. In 2015, the millionth tonne of Arctic Oil (known as ARCO) was extracted from the Prirazlomnoye field. The development of Prirazlomnoye is connected with much publicized Greenpeace protests in 2012 and 2013. Activists boarded the Prirazlomnaya platform on both occasions, protesting the extraction of oil in Arctic waters, claiming it to be environmentally unsafe and economically unfeasible (Greenpeace 2013).

In 2010, Gazprom transferred the licence for the Novoportovskoye oil, gas and condensate field, the largest in Yamal, to Gazprom Neft, and its subsidiary Gazprom Neft-Yamal became the operator of the Novy Port project. In 2014, development drilling started in the field. Gazprom Neft produced 2.5 million tonnes of crude in 2016 from Novoportovskoye and 5.95 million tonnes in 2017. The field is expected to yield 8 million tonnes of oil equivalent at its peak (Gazprom Neft 2019). Analysts warned that the Novoportovskoye field might be one of the first victims of Western sanctions, but Gazprom Neft managed to commission it nonetheless (Neftegazovaya vertikal 2015). The field is located about 700 kilometres from the existing (onshore) pipelines, and Gazprom Neft decided to transport Novy Port oil via the Polar Seas instead, delivering it through the Vorota Arktiki (Gates of the Arctic) offshore oil terminal (Fadeeva 2016b; Gazprom Neft 2018a). According to Gazprom Neft, zero discharge technology is used at the Vorota Arktiki terminal, which is fully automated and managed from the shore (Gazprom Neft 2016a).

In 2017, Gazprom Neft produced 62.3 million tonnes of oil, $4.3 \%$ more than 2016, thus becoming the third-largest oil producer in Russia. This growth was largely attributed to its new Arctic projects (Novy Port, East Messoyakha and Prirazlomnoye).

Like Sibneft in the 1990s, Gazprom Neft remained a trailblazer in the Russian oil sector. For example, the company requested the Ministry of Energy to include Novy Port on the list of projects subject to a new experimental tax on additional income that the Ministry had proposed to replace export duties and partially replace the mineral extraction tax. If successful, Gazprom Neft would become the first Russian oil company to transfer a major new project to this experimental tax regime (Kozlov 2018a). 
Gazprom Neft also tried, albeit with limited success, to establish joint ventures with Western companies. In addition to its long-term cooperation with Shell on the Salym Petroleum Development, it formed a 50:50 joint venture with Repsol in July 2017 to develop assets in the Kondinskiy region of Khanty-Mansi Autonomous District (Gazprom Neft 2017d).

Western sanctions have forced Gazprom Neft to look for partners elsewhere, namely in the Middle East. Thus, in December 2017, Gazprom Neft signed an agreement to sell $49 \%$ of Gazprom Neft-Vostok (East) for USD 325 million to the United Arab Emirates' Mubadala Investment Company and the Russian direct investment fund RFPI. Gazprom Neft-Vostok is developing a group of mature fields in the Tomsk and Omsk regions (Kozlov 2018b).

Like Sibneft, Gazprom Neft remained investors' favourite as the fastest-growing oil company in Russia with an expansive portfolio of new projects, which enjoyed tax benefits and had a strong management team. The only disadvantage was its minimal free float, the small proportion of its shares traded in the open market (Fadeeva 2016a).

\section{COMPANY PROFILE}

\section{Production Strategy}

Strategically, Gazprom Neft aims to adapt swiftly to external challenges. In the upstream segment, it focuses on cost control, optimization of the development of mature fields, import substitution, development of new technologies to raise oil recovery ratio, commissioning of hard-to-recover reserves, implementation of major onshore (Novy Port and Messoyakha) and offshore projects (Prirazlomnoye) and improving its competencies for working with non-conventional resources (Gazprom Neft 2018b).

In 2013, the company's board of directors approved a new 2025 strategy. The document extends the previous strategy, taking into account the changing conditions in the sector and the world economy. The key strategic objective of Gazprom Neft up to 2025 is to increase shareholder value through the efficient use of its resource potential and fuller commissioning of oil reserves, developing new sources of growth and maximizing the return on investments in new projects. It expects to achieve hydrocarbon production levels of 100 million tonnes of oil equivalent by 2020 as well as refining 40 million tonnes per annum of oil in Russia (Gazprom Neft 2017c). In late 2018, the board of directors of Gazprom Neft approved a new 2030 strategy that took into account changes that occurred in 2014, mainly lower oil prices and sanctions, as well as stricter global environmental standards and technological progress. The new strategy envisages that Gazprom Neft will remain among the world's top ten publicly traded oil companies in terms of oil production (Interfax 2019). 
Gazprom Neft's production strategy has two main components. The first component is to enhance its technological potential in partnership with companies such as Schlumberger, Halliburton and Shell. Under the strategy, Gazprom Neft aims to increase its oil recovery ratio from $30-35 \%$ to $55 \%$ by 2025 (Kozlov 2016). Gazprom Neft has already been successful in demonstrating quite impressive results in applying state-of-the-art technology to extract conventional reserves. It is one of the few companies in Russia that draw on chemical methods for enhancing oil recovery in mature fields (Gazprom Neft 2018b). In 2017, Gazprom Neft performed 30-stage hydrofracking in the Yuzhno-Priobskoye field in Khanty-Mansi Autonomous District, the first ever such operation in Russia (Gazprom Neft 2018b). In May 2018, Gazprom Neft signed an agreement with petroleum consultants DeGolyer \& MacNaughton (with whom it had been cooperating for ten years) on the choice and application of innovative technologies for enhancing the oil recovery ratio of the Southern licensing territory of the Priobskoye field. It is expected that the oil recovery ratio there could increase by 5-6\% (Gazprom Neft 2018c).

The second component of Gazprom Neft's production strategy involves commissioning new fields. This includes Prirazlomnoye on the Arctic continental shelf, the onshore Novy Port and Messoyakha projects. SeverEnergiya, a 50:50 joint venture between Gazprom Neft and Novatek, is another strategic priority for Gazprom Neft. Initially, it was an international venture involving ENI and Enel; however, following a series of share swaps in 2014, only Gazprom Neft and Novatek remained its shareholders. Arcticgaz is wholly owned by SeverEnergiya, which holds licences for the Samburgskiy block of fields. In total, recoverable reserves of SeverEnergiya amount to some 14.5 billion barrels of oil equivalent.

In 2017, Gazprom Neft was the first Russian company to cut down on its production following the agreement between Russia and OPEC. Gazprom Neft reduced its production by $2 \%$ in January 2017 compared to the $1 \%$ reduction rate achieved by most other Russian oil companies. However, the fall in Gazprom Neft's production may also be attributed to the severe cold weather that affected the output of the Novy Port and Prirazlomnoye projects and also slowed down the drilling at the company's more mature assets (Kozlov 2017a).

One of Gazprom Neft's main strategic priorities is to buy more of its supplies from Russian providers: it applies the existing Russian solutions and promotes the creation of new products in Russia. Gazprom Neft's enterprises have already been using domestic power-generating installations, onshore drilling rigs, pipes, catalysts for refining and so on (Gazprom Neft 2018d). 


\section{CSR}

Sibneft was a unique case of Russian-style corporate (or rather personal) social responsibility. Roman Abramovich became Governor of Chukotka in December 2000. At the time, the region was in a sorry state. Over the previous decade, its population had decreased by a factor of 3 to 50000 people; the outflow of residents from Chukotka was hindered only by a lack of funds to pay for flights. The indigenous population survived thanks to their reindeer; however, the headcount of reindeer fell from 500000 in the early 1990s to 100000 in 1999 (Proskurnina 2005).

Governor Abramovich's plan for the region had two main components. First, he radically improved the financial situation by registering the trading arms of Sibneft and Rusal in Chukotka. The profit tax from Slavneft-Trading and Sibneft-Chukotka accounted for about $60 \%$ of the regional budget revenues during Abramovich's tenure as governor. He also paid his own income tax of about USD 30 million per annum to the regional budget (Nikolaeva 2005). As a result, the total budget revenues of Chukotka increased more than eight-fold, and the tax revenue grew 40-fold. Sibneft also spent money on Chukotka via two charitable organizations: Territory and Pole of Hope (Polyus Nadezhdy). Besides the dramatic increase in the flows of money into the region, Abramovich also changed the budget management system by introducing the same model that has been applied in Sibneft.

As a result of these measures, Chukotka's economy began to improve. For instance, the average monthly salary rose by 3.5 times between 2000 and 2004. According to Konstantin Pulikovskiy, the authorised representative of the President in the Far Eastern District, Abramovich created the best system of regional management in Russia. Abramovich's first term in office ended in 2005, and although he was not particularly eager to remain in this position, he was elected for a second term. However, the new owner of Sibneft, Gazprom, had no intentions of helping Chukotka. A Gazprom representative once stated that 'the huge social allocations for the needs of Chukotka are the project of the former shareholders of Sibneft, not ours' (Proskurnina 2005).

Gazprom Neft performs CSR functions in a similar way to other Russian oil companies, with a focus on supporting social infrastructure and social projects in the regions where it operates. Like the other companies, it produces an annual sustainable development report, following the basic GRI standard (Gazprom Neft 2017j). The report presents Gazprom Neft's strategic management priorities in line with the UN's Sustainable Development Goals. The report outlines the company's sustainable development strategy, sustainability management and stakeholder engagement approach, corporate governance, human resource development, HSE protection, energy efficiency, supply chain responsibility, human rights, ethics and anti-corruption and community devel- 
opment activities. In his introductory message to the 2017 report, Alexander Dyukov made the following statement:

Today, the company's success at the international level is measured not only by its production and financial performance but also by the way it treats its employees, the territories where it operates and the environment. For Gazprom Neft, investment in human capital, concern for the safety of all production processes, protecting nature and developing social programmes are just as important tasks as the effective implementation of business projects. (Gazprom Neft 2017j, p. 7)

Dyukov also highlighted the Biosphera treatment facilities launched at the Moscow oil refinery in 2017. Costing RUB 9 billion, the facilities purify $99.9 \%$ of the refinery's wastewater. A similar project is also being rolled out at the Omsk oil refinery (Gazprom Neft 2017j, p. 7). To honour 2017 as the Year of Ecology in Russia, Gazprom Neft supported 1100 environmental protection measures, ranging from associated gas utilization in its operations to Arctic biodiversity protection. In 2017, it invested RUB 27 billion in environmental protection measures, almost double the amount invested in 2016 (Gazprom Neft 2017j, p. 96). In 2018, investments in environmental protection amounted to RUB 19 billion (Gazprom Neft 2018q, p. 102).

In the Sustainability Report 2018, Dyukov made the following statement:

In its activities, Gazprom Neft is consistently based on the principles of sustainable development. We measure success of the company not only by financial and operating indicators. Our key priorities are care about environment and prudent attitude to natural resources, safety, high technological level and systemic improvement of living standards in the regions where the company operates. (Gazprom Neft 2018q)

In the case of Messoyakha, Gazprom Neft demonstrated its ability to achieve compromises. The East Messoyakha licensing plot partially overlaps with the territory of the Messoyakha nature reserve, established to protect endangered animals and birds. Initially, there were plans to reduce the size of the reserve by some 40000 hectares. Surprisingly, the environmental protection bodies did not particularly object to this decision because they thought that this particular area of the reserve was the least valuable in terms of flora or fauna. But the residents of the Tazovskiy region were against the proposals and protested vociferously. The shareholders of Messoyakhaneftegaz (that is, Gazprom Neft and Rosneft) responded to public opinion in September 2014 by announcing that to protect the environment, they would abandon their plans to drill wells along the Messoyakha River and they would create a no-drill buffer zone. The local population supported this initiative in public hearings (SeverPress 2014).

In 2017, Gazprom Neft formalized its policy on interaction with indigenous minorities as well as its comprehensive guidelines on interaction with indig- 
enous peoples (Gazprom Neft 2017j, p. 124). When field development plans are being drafted for regions where indigenous peoples live, Gazprom Neft, in collaboration with the local authorities, usually organizes public hearings involving the indigenous peoples. Besides compensation measures for damage inflicted by its industrial activities, Gazprom Neft signs benefit-sharing agreements with the heads of indigenous families and provides material aid in accordance with these agreements. Over 200 such agreements were signed in 2016 (Gazprom Neft 2016b).

In 2017, the projects implemented under the socio-economic agreements (RUB 3.34 billion across five regions) included the construction of apartment buildings, a school and two sports complexes in Yamal-Nenets Autonomous District, a residential apartment block and an indoor ice-hockey rink in Khanty-Mansi Autonomous District. The grant programme (totalling RUB 25.7 million in 2017) supported projects such as an engineering skills tournament for young people, a creative skills development programme, a city festival in Khanty Mansiisk and a street art festival held in several cities (Gazprom Neft 2017j, pp. 122-34). Part of the social investment programme also focuses on building local supplier capacities to serve the industry. In 2017, Gazprom Neft concluded agreements with seven regions concerning the import substitution of lubricants and process fluids (Gazprom Neft 2017j, p. 124).

Gazprom Neft has a social investment programme called 'Native Towns'. All the company's main subsidiaries are involved in this programme. Lists of projects are compiled annually with due account for the needs of regional development and the opinion of stakeholders. The programme is implemented through cooperation agreements with the regional and local authorities and via Gazprom Neft's own social projects, a grant fund for local organizations and individual citizens, voluntary corporate actions and targeted charitable activities. In 2017, the Native Towns programme covered 35 regions with more than 2000 projects, 100 partner organizations and a total expenditure of more than RUB 20 billion (Gazprom Neft 2017j, p. 7).

A key principle of the Native Towns programme is the active involvement of Gazprom Neft's personnel in the implementation of social projects. To this end, the company also has a corporate volunteering programme which helps arrange sporting, educational and entertainment events for orphans, and children and adults with limited mobility (Gazprom Neft 2016b).

In 2018, RUB 6.8 billion were contributed by Gazprom Neft to the implementation of social projects under the Native Towns programme. By then, over 2350 social projects had already been completed, with 4773 employees acting as volunteers. The programme also has projects abroad: thus, Kustendorf CLASSIC helps young musicians and develops cultural ties between Russia and Serbia. It organizes concerts in the mountains of Serbia, and the pro- 
gramme consists of contests for young musicians, master-classes and performances by international classical music stars (Gazprom Neft 2018q).

In 2016, Gazprom Neft also provided financial support to the Russian Geographical Society, the Hermitage, the Saint Petersburg Yacht Club, the Russian Military and Historic Society, the Yamal Cooperation Foundation, UNESCO's International Assistance Foundation in Moscow, the Saint Petersburg Union of Journalists, the Federation of Figure-Skating in Yamal-Nenets Autonomous District and so on (Gazprom Neft 2016b).

\section{Offshore}

Gazprom Neft is the only Russian company that produces Arctic offshore oil, having commissioned the Prirazlomnoye field in the Pechora Sea in December 2013. However, its other Arctic offshore licences and its licences in the Sea of Okhotsk off Sakhalin Island are still only at the exploration stage.

Gazprom Neft recognizes that it needs foreign partners for the development of these fields; however, because of the Western sanctions in connection with the conflict in Ukraine, it mainly seeks potential allies in Asia. Thus, in 2016, Gazprom Neft and China National Offshore Oil Corporation (CNOOC) discussed opportunities for the joint development of offshore fields in Russia. In March 2017, during the Arctic Forum in Archangelsk, Gazprom Neft and Indian ONGC signed a framework agreement on Arctic offshore cooperation, focusing on exploration opportunities in the Dolginskoye field in the Pechora Sea. However, there are doubts about the capability of Chinese or Indian companies to replace the international oil companies in the challenging Arctic offshore ventures.

In 2017, Gazprom Neft-Sakhalin drilled the first well at the Ayashskiy block off Sakhalin Island in the Sea of Okhotsk. Originally Gazprom held the licence for this plot; however, in 2017, it transferred it to Gazprom Neft, which had managed to convince the parent company of the high oil-bearing potential of the plot (Kozlov 2017b). In October 2017, Gazprom Neft-Sakhalin discovered the Neptun field in the Sea of Okhotsk with geological reserves estimated at 255 million tonnes of oil equivalent (Alekseev 2017), and in November 2018, it discovered another field, Triton, with geological reserves estimated at 137 million tonnes of oil equivalent (Gazprom Neft 2018p). The company subsequently began seeking a partner to develop the Neptun field, in which Shell reportedly expressed interest (Neftianka 2018). The sea at the Ayashskiy block is only 62 metres deep; therefore, the project cannot be formally subject to the US sanctions that cover deep-water projects. Despite this, foreign companies proceed with caution about getting involved in such ventures. Following the discovery of Neptun, Alexander Dyukov confirmed that 'the development 
of the offshore assets of Gazprom Neft remains a strategic priority for the company' (Gazprom Neft 2017e).

Gazprom Neft-Sakhalin holds licences for four Russian Arctic offshore plots: Severo Vrangelevskiy (Eastern Siberian and Chukchi Seas), Kheisovskiy (Barents Sea) as well as Dolginskiy and Severo-Zapadniy plots (Pechora Sea). In 2015, Gazprom Neft lobbied for changes to the Dolginskoye field licence because it was not satisfied with the results of exploration drilling. Production in this field is now due to begin in 2031 rather than 2019 as was originally planned (Podobedova 2015).

\section{Shale Oil}

Gazprom Neft has expended significant amounts of capital on the development of hard-to-recover oil reserves. In total, the company has some 527 million tonnes of hard-to-recover reserves mostly in areas developed by its subsidiaries Gazprom Neft-Khantos in Khanty-Mansi Autonomous District and Gazprom Neft-Muravlenko in Yamal-Nenets Autonomous District (Gazprom Neft 2017i).

Experts from Gazprom Neft believe that the Bazhenov shale formation looks more attractive than the Arctic continental shelf east of the Urals mountains. Bazhenov is the world's largest shale oil formation. It is a 20-30 metre thick layer of rock at a depth of over two kilometres, extending throughout much of Western Siberia - a region that already has well-developed petroleum infrastructure. According to some estimates, its resources exceed 140 billion tonnes; however, it is characterized by a low oil recovery ratio of only $6-7 \%$ (Korostikov and Tarasenko 2019).

In September 2017, Gazprom Neft and the government of Khanty-Mansi Autonomous District signed an agreement to establish the Bazhenov Technological Centre in Khanty-Mansi Autonomous District. The parties agreed to cooperate on this national project to create domestic technology and equipment to develop the Bazhenov formation. The Bazhenov Centre will concentrate Gazprom Neft's state-of-the-art competencies and technologies as a basis for developing economically efficient methods and technologies. An area of the Krasnoleninskoye field has been designated to be used as a testing site for new technologies and equipment. In May 2017, a Gazprom Neft project to study the Bazhenov formation received national status with support from the Ministry of Energy and the Ministry of Natural Resources (Gazprom Neft 2017f).

Continuing this trend, in May 2018, Gazprom Neft, the Ministry of Industry and Trade and the government of Khanty-Mansi Autonomous District signed a MoU concerning the development of Bazhenov. Gazprom Neft will make investments and coordinate the activities of the technological partners. While 
the Ministry will encourage the signing of special investment contracts with technological partners, the government of Khanty-Mansi Autonomous District will create a favourable fiscal regime for these contracts. Gazprom Neft expects to produce 2.5 million tonnes of oil per annum from Bazhenov by 2025 (Gazprom Neft 2018h).

In October 2017, Gazprom Neft and the Engineering Centre of the Moscow Physical and Technical Institute established a Centre of R\&D Support for Hydrofracking in Saint Petersburg to develop optimal technological solutions for Bazhenov (Gazprom Neft 2017g). Gazprom Neft-Orenburg has also begun studying Domanicoid sediments, which are reserves of unconventional hydrocarbons in tight shale layers with forecast resources in the region of some 1 billion tonnes of oil (Gazprom Neft 2018o).

\section{Innovation}

Gazprom Neft's Innovative Development Programme aims to create technologies to enhance well productivity, develop the Bazhenov formation, improve oil recovery in depleted fields and manufacture catalysts for refining; the programme also aims to digitalize oil production, refining and marketing (Gazprom Neft, 2017j, p. 23).

A large part of Gazprom Neft's investment in innovation is focused on digital transformation (Gazprom Neft 2017j, p. 25). In April 2018, Gazprom Neft established a directorate for digital transformation led by Chief Digital Officer (CDO) Andrei Belevtsev. The directorate will work on creating a unified system of digital projects to radically improve the operating efficiency of all business processes and develop in-house services. Gazprom Neft plans to create an in-house IT platform to support services for generating new data flows and volumes and developing instruments for predictive analysis. The company expects to begin developing new products and services based on the introduction of state-of-the-art digital technologies.

In 2017-18, the company implemented a series of projects involving blockchain technology, artificial intelligence, predictive analysis, big data and the so-called digital twins of oilfields (Gazprom Neft 2018k). 'Digital twins' are virtual models of oilfields that change in tandem with regularly updated information which is passed from site-based sensors. The digital twins enhance the ability to predict technical issues and make timely decisions about equipment repairs, thus reducing operational costs (Gazprom Neft 2017j, p. 23).

Gazprom Neft aims to create the first 'digital plant' as part of a project to establish Russia's first digital platform for managing logistics, production and sales of petroleum products. The company has been working on this since 2017 and is cooperating with leading Russian IT companies and institutions, such as 
Tsifra, Skolkovo Institute of Science and Technology and Moscow Institute of Physics and Technology (Gazprom Neft 20181, 2018m).

In winter 2017-18, Gazprom Neft also tested an innovative and environmentally friendly approach to seismic exploration, using the green seismic technology at the Zapadno-Pokurskoy area in Khanty-Mansi Autonomous District. Besides reducing the anthropogenic impact on the environment, this technology draws on a wireless system of data transmission to enable the study of areas that are inaccessible by standard methods. Another pilot project (under Green Seismic 2.0) has been implemented in the same area. This project promotes the use of light drilling rigs and snowmobiles instead of heavy machinery as a way to avoid cutting down trees during seismic testing (Gazprom Neft 2018n).

\section{Internationalization}

In its 2025 strategy, which aimed to produce 100 million tonnes of oil equivalent per annum, Gazprom Neft predicted that its foreign upstream operations will account for at least $10 \%$ and places particular emphasis on Iraq and Venezuela (Neftegaz 2013). However, since investment risk in both countries is very high, due to political instability, Gazprom Neft has been searching for other attractive opportunities, albeit with somewhat mixed results.

One of Gazprom Neft's most important international upstream acquisitions was made in December 2008 when it purchased a 51\% share of the Serbian company Naftna Industrija Srbije (NIS) for EUR 400 million when NIS was privatized. The government wholly owned NIS with fields in Serbia and Angola as well as two refineries and 486 fuel stations in Serbia (Tutushkin 2008b). In 2011, Gazprom Neft bought another 5.15\% of NIS, raising its stake to $56.15 \%$. Serbia is the only European country in which Gazprom Neft produces oil. Via NIS, Gazprom Neft also operates in Hungary and Romania, albeit at the exploration stage.

From 2008, hoping to make its presence felt in the Middle East, Gazprom Neft initially looked to Iran. In November 2009, it signed a MoU with the National Iranian Oil Company (NIOC) concerning the Anaran block in western Iran (Tutushkin 2009a). However, being dissatisfied with Gazprom Neft's passivity, NIOC terminated the MoU in 2011 and started seeking new partners. Tehran allegedly had the impression that since Gazprom Neft produced oil in Iraq, Iran was of little genuine interest to it (Raibman 2011). However, according to other reports, Gazprom Neft dragged its feet and eventually gave up the project because Gazprom proper was not keen to work in a country under international sanctions (Melnikov and Gabuev 2011).

A major upstream breakthrough for Gazprom Neft was achieved in Iraq. In January 2010, the Iraqi government signed a contract with the winner of 
an international tender to develop the Badra project in eastern Iraq. The consortium comprised Gazprom Neft (30\%, operator), Kogas (22.5\%), Petronas (15\%) and Turkish Petroleum (TPAO) (7.5\%), with the Iraqi Oil Exploration Company (OEC-Iraq) keeping a 25\% share. In 2014, Gazprom Neft launched the commercial development of the Badra oilfield. This was the first major international E\&P project that it started from scratch. In 2012, Gazprom Neft secured further projects in Iraq (Gazprom Neft 2018f). In 2013, Gazprom Neft expanded its presence to Kurdistan in northern Iraq where it became the operator of a project (with an $80 \%$ stake) to develop the Halabja block with estimated reserves of some 100 million tonnes of oil (Solodovnikova 2013a).

Venezuela has been another potential growth area for Gazprom Neft. In 2008, the National Oil Consortium was established in which Gazprom Neft was an equal partner with Rosneft, LUKOIL, TNK-BP and Surgutneftegas. In spring 2010, the joint venture PetroMiranda was set up to develop the Junin-6 block in Venezuela's Orinoco River basin. PetroMiranda comprised the National Oil Consortium with $40 \%$ and Corporacion Venezolana del Petroleo, a subsidiary of Venezuela's PDVSA, with $60 \%$. Forecasts of recoverable reserves of Junin- 6 are estimated at 10.96 billion barrels of oil, and the first oil was produced in 2012 (Gazprom Neft 2018g). Initially, Gazprom Neft was appointed to coordinate the activities of all the Russian companies; however, later Rosneft took over this role. Gradually, other companies quit the National Oil Consortium, leaving behind Rosneft (80\%) and Gazprom Neft (20\%).

Gazprom Neft sought to introduce itself as a strong player in international offshore projects, but without much success. In 2010, it concluded an agreement with Petronas and began working on the Cuban continental shelf. In July 2011, it signed a contract to cooperate with Petronas and the state-owned Cuba Oil Union (CUPET). However, having spent some USD 12 million, Gazprom Neft decided to abandon the project on the Cuban continental shelf in February 2013 without having found any oil (Solodovnikova 2013b).

In mid-2010, Gazprom Neft, Guinean GEPetrol and the Ministry of Energy of Equatorial Guinea signed a production-sharing agreement relating to two oil blocks on the continental shelf of Equatorial Guinea. It was to be the first Russian oil project in Equatorial Guinea, where US companies had hitherto dominated (Peretolchina et al. 2010). However, in 2014, Gazprom Neft left the project, deeming it insufficiently attractive (Mordyushenko 2014).

Gazprom Neft also tried to secure a stake in the (onshore) Elephant Field in south-west Libya. Gazprom reached a preliminary agreement with ENI in 2008 during a multi-stage asset swap with the Italian company; however, because of the hostilities in Libya, Gazprom Neft's expectations did not materialize.

Downstream, Gazprom Neft focuses on expanding its niche in the fuel markets of the CIS. In 2006, Gazprom Neft entered the Central Asian retail market and founded a subsidiary, Gazprom Neft-Asia. In 2006, Gazprom Neft 
bought some 100 fuel stations in Kyrgyzstan for USD 99 million. It became the second Russian oil company (after Alliance) to enter the Kyrgyz market (Tutushkin 2006). In 2010, Gazprom Neft bought a network of 20 fuel stations from the Kazakh company ARNA Petroleum along with nine land plots for the construction of new fuel stations (Tutushkin and Vasilev 2010).

Gazprom Neft's advance downstream in Europe was not particularly successful after its initial breakthrough with NIS in Serbia. Gazprom Neft was interested in Greece and hoped to participate in the privatization of a stake in Hellenic Petroleum in 2012 (Melnikov et al. 2012). It also wished to gain a foothold in Albania and planned to take part in the privatization of Albpetrol (Mazneva 2012). However, neither of these ambitions materialized. Gazprom Neft, however, was more fortunate in Italy. In early 2009, Gazprom Neft bought the oil- and lubricant-producing plant Chevron Italia, located in the port city of Bari on the Adriatic Sea, with a capacity of 30000 tonnes of oil and 6000 tonnes of lubricant per annum (Tutushkin 2009b).

Gazprom Neft also tried to gain a foothold downstream in Asia. In November 2013, during Vladimir Putin's visit to Vietnam, Gazprom Neft signed a framework agreement to purchase part of the Dung Quat refinery from Petrovietnam (Serov and Chelpanova 2013). However, in January 2016, it broke off negotiations with Petrovietnam because it was dissatisfied with the position of the Vietnamese Ministry of Industry and Trade, which did not intend to retain preferential import tariffs for the refinery (Neftegazovaya vertikal 2016).

\section{COPING WITH THE CHALLENGE OF CHANGE}

\section{Crises, Oil Prices and Sanctions}

Like other Russian companies, Sibneft/Gazprom Neft is seriously affected every time the oil prices fall. When the oil prices dropped in 1998, and the Russian financial system crashed, Sibneft engaged in cost reduction. It cut the investment programme of Noyabrskneftegaz by drastically reducing its considerable expenditures, which included capital construction and drilling. It also decided to uncouple Noyabrskneftegaz from its oil service facilities (Neft, gaz i fondovyy rynok 2008).

In the aftermath of the 2008 oil price collapse, Gazprom Neft lost more than USD 20 billion of its year-end capitalization. However, Gazprom Neft's response was somewhat interesting: It bought out $0.44 \%$ of its shares to support liquidity, obtaining them at minimum prices. The company expected that once the crisis had passed, the shares could be sold or used for the options programme for managers (Mazneva 2009). Despite the crisis, Gazprom Neft doubled its expenditure on the 1286 staff at its headquarters in 2010 (Gavshina 
2010). It is not easy to determine whether this development was driven by a proactive human resources policy or reflected a principal-agent problem.

Gazprom Neft is of course well aware of the importance of oil price dynamics and identifies the following macroeconomic factors that affect its work: changes of market prices of oil and petroleum products, dynamics of the rouble/dollar exchange rate and inflation, taxation and changes in tariffs for the transportation of oil and petroleum products (Gazprom Neft 2018b).

The company's leadership closely monitors the oil price landscape and maps out its strategy accordingly. Hence, in 2016, Alexander Dyukov announced that the company assumed that the oil prices would be USD 50-60 per barrel over three years. The initial forecast of the company for 2016 was USD 25-30 per barrel. Dyukov emphasized that the company could comfortably operate at USD 25 per barrel (Fadeeva 2016).

In its 2016 Annual Report, Gazprom Neft stated that the dynamics of supply and demand, the reduction of excess oil in the market and changes in the tactics of oil producers mitigated the risks of price volatility in the short term. The company expected that the following factors would impact the oil market in 2017: a rise in the world's oil consumption, the OPEC+ agreement, the dynamics of oil production in the United States and the geopolitical limitations of oil production in certain OPEC member countries (Gazprom Neft 2018b).

The attitude of the company towards the challenges of oil price volatility and sanctions is well described by Sergei Vakulenko, Head of Gazprom Neft's Department of Strategy and Innovations. According to him, before 2014 (that is, in the pre-sanctions period) raising capital was easy, and the whole oil sector was in a hurry to accumulate as many assets as possible, believing that whoever expanded fastest would win (Vakulenko 2018). In this respect, claims Vakulenko, Gazprom Neft was fairly unique. It demonstrated the highest growth rates in the sector, and they were achieved because of a well-thought-out plan. Gazprom Neft calculated from the very beginning how many and what projects it needed at a specific stage of its development; when they were accomplished, only then were new projects chosen. This principle guided the company before 2014, and it remains relevant today. However, Gazprom Neft undoubtedly also had to revise some of its projects given the altered economic conditions. For example, the upgrading of refineries was slightly delayed due to budget constraints. The company changed its approach to high-cost production projects; it did not give them up completely but tried to cut costs as much as possible. In general, the business model that Gazprom Neft adopted turned out to be viable and survived the acid test of sanctions.

Vakulenko commented that due to the specifics of the domestic revenue-based tax system, Russian oil companies learned how to work efficiently with very 
low oil prices. Even when the oil prices were above USD 100 per barrel, for the Russian oil companies, the prices did not exceed USD 35-40.

If we speak about the next $2-3$ years, such specific things as wars, revolts, natural disasters, that is any global disturbances in oil-producing regions, might significantly affect the production potential. Recall that the period of the great growth of oil prices that resulted in USD 146 per barrel in 2008 began with Hurricane Katrina in 2003. From a different perspective, that period was also characterized by high economic growth that pushed oil demand upwards. Now, an unstable global political situation contributes to the dampening of economic activity. (Gazprom Neft 2018e)

Sanctions and low oil prices threatened Gazprom Neft's most ambitious upstream projects, such as Prirazlomnoye. However, in late 2014, Gazprom Neft was confident that this offshore project would be profitable even with a considerable decline in oil prices. Interestingly, in early 2014, Alexander Dyukov commented that the fiscal benefits granted to the project would ensure the efficiency of the Prirazlomnoye development even if oil prices dropped to USD 80 per barrel (Neftegazovaya vertikal 2015). The subsequent events, however, showed that he was overly optimistic in his oil price forecast (albeit realistic in assessing the value of state support).

To survive low oil prices, Gazprom Neft successfully lobbied for significant fiscal benefits: the mineral production tax was reduced to zero for the Prirazlomnoye field; this waiver was initially provided up to 2019 but was later extended to 2022. From April 2014 a lower rate of export duty was also granted for Prirazlomnoye oil. In July 2014, the Ministry of Natural Resources proposed transferring Prirazlomnoye from the second to the third category of project complexity, which meant the mineral production tax would be reduced from $15 \%$ to $10 \%$ after a certain level of production was achieved. Also, a tax manoeuvre helped the project by lowering even more export duty, thus making it possible for Prirazlomnoye to succeed in the face of low oil prices (Neftegazovaya vertikal 2015).

Still, in March 2016, Gazprom Neft wrote a letter to the Ministry of Natural Resources complaining about the adverse effects of the sanctions and declining oil prices on the company's ability to invest in offshore exploration and demanding to have financial benefits for its offshore exploration projects (Starinskaya 2016).

In 2017, a new budget rule for the Russian petroleum sector was introduced. In 2018, all additional income generated when the oil prices exceeded USD 40 per barrel was to be channelled to a special reserve fund. Gazprom Neft adhered to this rule. When approving the business plan for the subsequent three years, Gazprom Neft proceeded from the forecast macroeconomic indicators determined by the Ministry of Economic Development: an expected price 
of USD 44 per barrel for Urals oil and a USD/RUB exchange rate of 64. All additional income was channelled to the fund designated by the budget rule; the company would use it to repay creditors, pay dividends and finance its investment programmes. Experts believed that these accumulations might be necessary for Gazprom Neft to reduce risks, presumably because of the sanctions (Petlevoy et al. 2018).

In early February 2018, Alexander Dyukov said that the scenario whereby the participants of the OPEC+ agreement would make greater oil production cuts seemed unacceptable. 'We would still hope that the production quotas would increase. You see that demand is growing, the price is also growing. The market is close to stabilization; therefore, if we proceed from what we observe now, I will accept this scenario' (Dyukov, cited in Starinskaya 2018).

When Western countries imposed sanctions on Russia and its petroleum sector over the conflict in Ukraine, Gazprom Neft began searching for partners for its offshore projects in the East. 'After the introduction of the sanctions regime, these activities [in offshore fields] became more complicated, but the Eastern direction - the direction of the Asia-Pacific region - permits saying that the companies are interested or express interest in our projects, and we hope to work in this direction', said Andrei Patrushev, the Deputy Director of Gazprom Neft for the development of offshore projects, in summer 2016 (Petlevoy 2017).

Western sanctions also had an unexpected indirect impact on Gazprom Neft: taking advantage of the growing anti-Russian sentiment in Europe, Serbia tried to revise the terms for the privatization of NIS. The Serbian Ministry of Internal Affairs began to investigate the privatization deal (Neftegazovaya vertikal 2015). However, because of Gazprom Neft's political connections and support from the Russian government, it managed to weather the storm.

\section{Climate Change}

Gazprom Neft is working on the assumption that hydrocarbons will continue to play a key role in the world's economy in the future, supplying some $90 \%$ of the primary energy. In assessing the global dynamics of hydrocarbon supply and demand, the company uses data from the US Energy Information Administration and the IEA in its 2017 Annual Report.

Like many of its Russian counterparts, Gazprom Neft does not seem to consider climate change a serious issue. Its 2016 Sustainability Report mentions the word 'climate' only twice, once on page 36 in connection with the UN's 
Sustainable Development Goals (Gazprom Neft 2016b) and another time in a very general context:

Gazprom Neft is one of the leaders of the Russian oil sector and recognizes its responsibility for preserving the natural environment for the current and future generations. The problem of climate change strengthens the importance of this issue and activities aimed at reducing emissions at the level of the company and the country as a whole. Solving this task, the company implements the programme to raise the level of APG utilization at all its oil-producing assets.

Gazprom Neft's attitude towards renewable energy is reflected in an interview with Sergei Vakulenko, Head of the Department of Strategy and Innovations:

If we speak about alternative energy: solar, air and water, electric vehicles and so on, we certainly take them into account in our strategy but in a much longer-term perspective. The speed of this development will be determined by a whole range of factors, such as the rates of improvement of battery-manufacturing technologies, the desire of governments to carry out social engineering, prompting people to make a transition to electric cars and the readiness of people to do this. In a very extreme scenario, people from developed countries may decide that global warming is exceptionally serious and to mitigate it, they will have to sacrifice part of their income so that growing car ownership in the developing countries will follow the electric path. Under such developments, demand for oil would indeed decrease more rapidly than what people envisage now. But this is on the condition that the countries of the first world are rich enough to agree to this, and it involves a whole spectrum of factors, such as technological readiness and the availability of raw materials and not only lithium, about which everybody seems to know, but also cobalt, neodymium for permanent magnets and so on. (Gazprom Neft 2018e)

Vakulenko believes that peak demand for oil in 2040-50 is quite possible and probable: 'The trend will be determined by the degree to which people will be concerned about environmental issues' (Gazprom Neft 2018e).

Gazprom Neft monitors GHG emissions generated through its activities: both direct and indirect GHG emissions related to third-party consumption of electricity, heat, steam and so on (Gazprom Neft 2016b). According to its 2016 Sustainability Report, the total volume of GHG emissions in 2016 amounted to 16 million tonnes of $\mathrm{CO}_{2}$ equivalent, a $28 \%$ rise from 2015 . This increase is due to the commissioning of major new fields where infrastructure for utilizing associated petroleum gas (APG) would be built later on; the rise in GHG emissions is also ascribable to the increased consumption of heat and electricity because of an unusually cold winter. In 2018, the company's GHG emissions amounted to 19 million tonnes of $\mathrm{CO}_{2}$ equivalent due to increased APG flaring and oil refining (Gazprom Neft 2018q, p. 105) (Figure 4.2). 


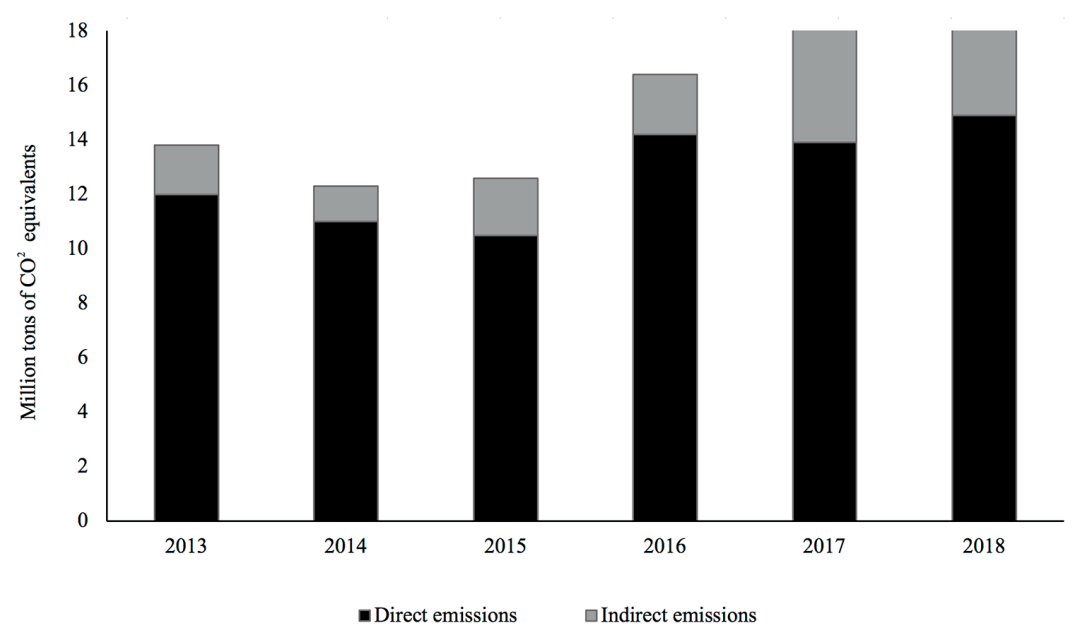

Figure 4.2 Gazprom Neft GHG emissions

Source: Gazprom Neft (2016b, p. 98, 2018q, p. 105).

In practice, the utilization of APG is Gazprom Neft's main contribution to climate change mitigation. Already in 2012, it signed an agreement with SIBUR on implementing the Noyabrsk Integrated Project for the Vynagapurovskaya group of five fields in Yamal-Nenets Autonomous District. APG produced from these fields was to be delivered to the newly built Vynagapurovskiy gas-processing plant of SIBUR (Neftegaz 2012). Cooperation with SIBUR in utilizing APG continued: in September 2015, Gazprom Neft and SIBUR commissioned the Yuzhno-Priobskiy gas-processing plant with a capacity of 900 million cubic metres of APG per annum (Gazprom Neft 2015). Continuing this trend, in April 2018, Messoyakhaneftegaz started a unique practice of injecting APG from East Messoyakha field into the gas cap of the West Messoyakha field. This is also a way of storing gas for future use (Gazprom Neft 2018i).

In February 2018, Gazprom Neft began testing the installation of a complex gas treatment system and its injection into reservoirs in the Novoportovskoye field. This installation will permit the utilization of $95 \%$ of the field's APG. Processed APG from the installation will also be used as fuel for the largest gas-turbine power station in Yamal (Gazprom Neft 2018j). Gazprom Neft seeks to enhance the energy efficiency of its operations and optimize the utilization of energy resources. This work is incorporated into the company's energy strategy and follows ISO 50001:2011 (Gazprom Neft 2016b).

Gazprom Neft also aims to increase APG utilization in its foreign operations. Thus, in December 2017, the company began commercial operation of 
the installation for gas processing at the Badra field. Dry gas prepared at the Badra field is transported to the Az-Zubaidiya power station; gas is also used for the needs of the Badra project as fuel for a gas-turbine power station. As Alexander Dyukov noted, the installation will enable the monetization of all hydrocarbons produced in the field and ensure a 95\% level of APG utilization (Gazprom Neft 2017h).

Through its Serbian subsidiary NIS, Gazprom Neft started experimenting with the renewables business. Since 2011, NIS has been transforming itself from an oil and gas company into an energy holding which develops, among other things, renewables (geothermal and wind). NIS uses geothermal energy for heating purposes. In 2016, NIS also completed the site for the construction of its own wind farm in Plandishte with a capacity of $100 \mathrm{MW}$ consisting of 40 wind generators (Gazprom Neft 2016b). Gazprom Neft also has very small-scale wind and solar projects in Yamal where some remote sites consume electricity generated by wind, solar and diesel installations combined.

\section{CONCLUSION}

Gazprom Neft is the result of the transformation of the former 'robber baron' Sibneft, which was involved in several major corporate controversies in Russia, into a subsidiary of Gazprom, which is better known for its consistency and stability as the blue whale of the Russian gas sector. Gazprom Neft continues to manifest a fairly entrepreneurial approach to the oil business, differentiating it from its parent company. It has also proved to be a doer that has managed to launch the three largest Arctic oil projects in Russia (including the first ever Russian Arctic offshore project). Having received strong support from the state, it has overcome macroeconomic problems and geopolitical challenges. It is also a digital pioneer of the Russian petroleum sector.

Although the posts of the chairman of the board of directors and the company director passed between different people, partly reflecting changes in Russia's political configuration, the leadership of Sibneft was dominated by the larger-than-life characters of Roman Abramovich and Boris Berezovskiy. Since being taken over by Gazprom, the leadership of Gazprom Neft has become more stable. Alexander Dyukov has been the CEO and chairman of the management board of Gazprom Neft since 2008.

Gazprom Neft turned its back on the patronage that Sibneft had shown to Russia's Far Eastern province of Chukotka and continues its CSR activities along the more traditional lines of Russian oil companies, with a focus on social projects in the regions of its operations. On the issue of climate change, Gazprom Neft holds a somewhat sceptical position, expecting hydrocarbons to dominate future development scenarios; despite this, it has made considerable investments in operational efficiency and utilization of APG. 


\section{NOTE}

1. Use of pressurized water to maximize oil extraction.

\section{REFERENCES}

Alekseev, A. (2017), 'Yavlenie Neptuna', accessed 16 October 2018 at http://www .gazprom-neft.ru/press-center/sibneft-online/archive/2017-october/1205484/.

Baraulina, A., I. Malkova and A. Tutushkin (2009), 'Inostrantsy prodali Sibir', accessed 15 October 2018 at https://www.vedomosti.ru/newspaper/articles/2009/04/ 24/inostrancy-prodali-sibir.

Borisov, N. (2005), 'Sibneft budet schedroy', accessed 15 October 2018 at https:// neftegaz.ru/press/view/1958.

Derbilova, E. (2005), 'Millhouse pomog Gazpromu', accessed 15 October 2018 at https://www.vedomosti.ru/newspaper/articles/2005/09/13/millhouse-pomog -gazpromu.

Egorova, T. (2006a), 'Sibneft nashla kadry', accessed 15 October 2018 at https://www .vedomosti.ru/newspaper/articles/2006/04/04/sibneft-nashla-kadry.

Egorova, T. (2006b), 'Kak Abramovichu', accessed 15 October 2018 at https://www .vedomosti.ru/newspaper/articles/2006/05/24/kak-abramovichu.

Fadeeva, A. (2016a), 'Gazprom Neft khochet ostatsya sredi liderov po neftedobyche', accessed 15 October 2018 at https://www.vedomosti.ru/business/articles/2016/06/ 14/645165-gazprom-neft.

Fadeeva, A. (2016b), 'Gazprom Neft otpravila pervyi tanker nefti s Novoportovskogo mestorozhdeniya', accessed 15 October 2018 at https://www.vedomosti.ru/business/ articles/2016/05/26/642469-gazprom-neft-novoportovskogo.

Forbes (2011), 'Abramovich: Slukhi o Berezovskom kak aktsionere Sibnefti pomogali kompanii', accessed 15 October 2018 at http://www.Forbes.ru/news/75963 -abramovich-sluhi-o-berezovskom-kak-aktsionere-sibnefti-pomogali-kompanii.

Gavshina, O. (2010), 'Neftyanye kompanii - lidery po rostu raskhodov na personal', accessed 16 October 2018 at https://www.vedomosti.ru/management/articles/2010/ 08/18/platyat_bolshe.

Gavshina, O. (2011), 'Sovmestnoe predpriyatie Gazprom Nefti i TNK-BP vykupit proekt u dochki', accessed 15 October 2018 at https://www.vedomosti.ru/business/ articles/2011/01/12/podelili_neft.

Gazprom Neft (2016a), 'Nachalas otgruzka Yamalskoy nefti cherez morskoi terminal "Vorota Arktiki”", accessed 23 January 2019 at https://www.gazprom-neft.ru/press -center/news/1113215/.

Gazprom Neft (2016b), Gazprom Group's Sustainability Report 2016, accessed 16 October 2018 at http://www.gazprom-neft.com/social/reports/.

Gazprom Neft (2017a), 'Istoriya kompanii', accessed 11 October 2018 at http://www .gazprom-neft.ru/company/history/.

Gazprom Neft (2017b), 'Geologorazvedka i dobycha nefti i gaza', accessed 11 October 2018 at http://www.gazprom-neft.ru/company/business/exploration-and -production/.

Gazprom Neft (2017c), 'Gazprom Neft vkratse', accessed 11 October 2018 at http:// www.gazprom-neft.ru/company/at-a-glance/. 
Gazprom Neft (2017d), 'Sovet direktorov Gazprom Nefti rassmotrel voprosy strategicheskogo razvitiya kompanii', accessed 15 October 2018 at http://www.gazprom -neft.ru/press-center/news/1247213/.

Gazprom Neft (2017e), 'Gazprom Neft otkryla novoe mestorozhdenie na shelfe Okhotskogo morya', accessed 16 October 2018 at http://www.gazprom-neft.ru/press -center/news/1166741/.

Gazprom Neft (2017f), 'Gazprom Neft i pravitelstvo KHMAO podpisali soglashenie o sozdanii Technologicheskogo Centra Bazhen', accessed 16 October 2018 at http:// www.gazprom-neft.ru/press-center/news/1133299/.

Gazprom Neft (2017g), 'Gazprom Neft i MFTI sozdali nauchno-technicheskiy tsentr dlya soprovozhdeniya i izucheniya GRP v Bazhenovskoy svite', accessed 16 October 2018 at http://www.gazprom-neft.ru/press-center/news/1189202/.

Gazprom Neft (2017h), 'Gazprom Neft vvela v promyshlennuyu ekspluatatsiu gazovyi zavod na mestorozhdenii Badra v Irake', accessed 16 October 2018 at http://www .gazprom-neft.ru/press-center/news/1263566/.

Gazprom Neft (2017i), 'V Gazprom Neft-Khantose sozdan tsentr upravleniya dobychey, ispolzuyuschiy technologiu tsifrovykh dvoinikov', accessed 16 October 2018 at http://www.gazprom-neft.ru/press-center/news/1226891/.

Gazprom Neft (2017j), Aiming Higher: 2017 Sustainability Report, accessed 9 February 2019 at http://ir.gazprom-neft.com/fileadmin/user_upload/documents/ annual_reports/gpn_csr2017_eng_200718.pdf.

Gazprom Neft (2018a), 'Proekt Novyy Port', accessed 15 October 2018 at http://www .gazprom-neft.ru/company/business/exploration-and-production/new-projects/new -port/.

Gazprom Neft (2018b), Gazprom Neft 2017 Annual Report, accessed 15 October 2018 at http://ir.gazprom-neft.com/fileadmin/user_upload/documents/annual_reports/gpn ar17_eng.pdf.

Gazprom Neft (2018c), 'Gazprom Neft povyshaet effectivnost razrabortki Priobskogo mestorozhdeniya vmeste s DeGolyer and McNaughton', accessed 15 October 2018 at http://www.gazprom-neft.ru/press-center/news/1646773/.

Gazprom Neft (2018d), 'Sovet direktorov Gazprom Nefti rassmotrel mery po minimizatsii doli importnykh zakupok', accessed 16 October 2018 at http://www.gazprom -neft.ru/press-center/news/1638994/.

Gazprom Neft (2018e), 'Gazprom Neft: Osnovnye idei strategicheskogo razvitiya', accessed 16 October 2018 at http://www.gazprom-neft.ru/press-center/lib/1642212/.

Gazprom Neft (2018f), 'Gazprom Neft vvela v ekspluatatsiyu vtoruyu skvazhinu na mestorozhdenii Sarqala', accessed 16 October 2018 at http://www.gazprom-neft.ru/ press-center/news/1526676/.

Gazprom Neft (2018g), 'Mezhdunarodnye proekty', accessed 16 October 2018 at http:// www.gazprom-neft.ru/company/business/exploration-and-production/international -projects/.

Gazprom Neft (2018h), 'Gazprom Neft, Minpromtorg i pravitelstvo KHMAO-Ugry podtverdili sotrudnichestvo v proekte osvoeniya Bazhenovskoy svity', accessed 16 October 2018 at http://www.gazprom-neft.ru/press-center/news/1621476/.

Gazprom Neft (2018i), 'Messoyakhaneftegaz realizuet unikalnyi proekt po utilizatsii poputnogo neftyanogo gaza', accessed 16 October 2018 at http://www.gazprom-neft .ru/press-center/news/1509719/.

Gazprom Neft (2018j), 'Gazprom Neft nachala puskonaladochnye raboty na ustanovke kompleksnoy podgotovki gaza Novoportovskogo mestorozhdeniya', accessed 16 October 2018 at http://www.gazprom-neft.ru/press-center/news/1442588/. 
Gazprom Neft (2018k), 'Tsifrovizatsiya stanet novym biznes-napravleniem Gazprom Nefti', accessed 16 October 2018 at http://www.gazprom-neft.ru/press-center/news/ $1509691 /$.

Gazprom Neft (20181), 'Gazprom Neft sozdaet pervyi tsifrovoy zavod', accessed 16 October 2018 at http://www.gazprom-neft.ru/press-center/news/1621474/.

Gazprom Neft (2018m), 'Gazprom Neft sozdaet sobstvennuyu tsifrovuyu technologiu razrabotki mestorozhdeniy', accessed 16 October 2018 at http://www.gazprom-neft .ru/press-center/news/1526739/.

Gazprom Neft (2018n), 'Gazprom Neft rasshiryaet primenenie zelenykh technologiy v seismorazvedke', accessed 16 October 2018 at http://www.gazprom-neft.ru/press -center/news/1595456/.

Gazprom Neft (2018o), 'Sovet Direktorov Gazprom Nefti rassmotrel vopros o perspektivakh razvitiya Orenburgskogo neftedobyvayuschego klastera', accessed 15 October 2018 at http://www.gazprom-neft.ru/press-center/news/1509639/.

Gazprom Neft (2018p), 'Gazprom Neft otkryla vtoroye mestorozhdeniye na shelfe Okhotskogo Morya', accessed 29 June 2019 at https://www.gazprom-neft.ru/press -center/news/2021843/.

Gazprom Neft (2018q), Sustainability Report 2018, accessed 3 December 2019 at https://csr2018.gazprom-neft.ru/.

Gazprom Neft (2018r), 'Gazprom Neft at a glance', accessed 3 December 2019 at https://www.gazprom-neft.ru/company/about/at-a-glance/.

Gazprom Neft (2019), 'Proetk Novy Port', accessed 23 January 2019 at https://www .gazprom-neft.ru/company/business/exploration-and-production/new-projects/new -port/.

Greenpeace (2013), 'Aktivisty Greenpeace zabralis na platformu Prirazlomnaya', accessed 15 October 2018 at http://www.greenpeace.org/russia/ru/news/2013/18-09 -action-on-Prirazlomnaya/.

Interfax (2019), 'Strategiya Gazprom Nefti do 2030 goda: Rasti v dobyche bystree rynka i stat etalonom otrasli', accessed 20 December 2019 at https://www.interfax .ru/business/656140.

Knyazev, M. (2010), 'Roman Abramovich i ego pomoschnik', accessed 15 October 2018 at http://www.forbes.ru/ekonomika/lyudi/54248-roman-abramovich-i-ego -pomoshchnik.

Korostikov, M. and P. Tarasenko (2019), 'V Venezuele udvoilos chislo presidentov', accessed 26 January 2019 at https://www.kommersant.ru/doc/3861496?from=doc mail.

Kozlov, D. (2016), 'Gazprom Neft stavit na novuyu neft', accessed 15 October 2018 at https://www.kommersant.ru/doc/3012559.

Kozlov, D. (2017a), 'S peresokrascheniem plana', accessed 16 October 2018 at https:// www.kommersant.ru/doc/3208080.

Kozlov, D. (2017b), 'Gazprom Neft nashla neft na shelfe', accessed 16 October 2018 at https://www.kommersant.ru/doc/3429161.

Kozlov, D. (2018a), 'Gazprom Neft derzhitsya za lgoty', accessed 15 October 2018 at https://www.kommersant.ru/doc/3542454.

Kozlov, D. (2018b), 'Arabskie investory nashli dobychu v Rossii', accessed 15 October 2018 at https://www.kommersant.ru/doc/3549668.

Landes, A. and A. Nagaria (2003), 'Russian oil and gas: Taking stock', Renaissance Capital Research, 1-2. 
Lenta.ru (2003), 'ExxonMobil vedet peregovory o pokupke kontrolnogo paketa YUKOS-Sibnefti', accessed 23 January 2019 at https://enta.ru/news/2003/10/03/ exxon/.

Lysova, T. (2005), 'Kompaniya nedeli: Puteshestviye Sibnefti', accessed 15 October 2018 at https://www.vedomosti.ru/newspaper/article.shtml?2005/09/29/97641.

Malkova, I. and E. Mazneva (2007), 'Neft na dvoikh', accessed 15 October 2018 at https://www.vedomosti.ru/newspaper/articles/2007/12/28/neft-na-dvoih.

Malkova, I. and I. Reznik (2006), 'Kto upravlyaet Gazpromom', accessed 15 October 2018 at https://www.vedomosti.ru/newspaper/articles/2006/11/22/kto-upravlyaet -gazpromom.

Mazneva, E. (2007), 'Gazpromu ne khvataet deneg', accessed 15 October 2018 at https://www.vedomosti.ru/newspaper/articles/2007/11/09/gazpromu-ne-hvataet -deneg.

Mazneva, E. (2009), 'Snova lider', accessed 16 October 2018 at https://www.vedomosti .ru/newspaper/articles/2009/04/16/snova-lider.

Mazneva, E. (2010a), 'Gazprom Neft zakhvatila somnitelnoe liderstvo - po zatratam na dobychu', accessed 15 October 2018 at https://www.vedomosti.ru/business/articles/ 2010/08/19/spornoe_liderstvo.

Mazneva, E. (2010b), 'Tsena Sibir Energy', accessed 15 October 2018 at https://www .vedomosti.ru/newspaper/articles/2010/05/26/cena-sibir-energy.

Mazneva, E. (2011), 'Khozyaika Sibir Energy', accessed 15 October 2018 at https:// www.vedomosti.ru/newspaper/articles/2011/02/16/hozyajka_sibir_energy.

Mazneva, E. (2012), 'Gazprom Neft mozhet kupit Albpetrol', accessed 16 October 2018 at https://www.vedomosti.ru/business/articles/2012/07/18/gazprom_idet_v albaniyu.

Meīnikov, K. and A. Gabuev (2011), 'Gazprom Nefti nashli dublera', accessed 16 October 2018 at https://centrasia.org/newsA.php?st=1318565640.

Melnikov, K., E. Kuznetsova and A. Gudkov (2012), 'Grecheskiy benzin ischet rossiyskikh pokupateley', accessed 16 October 2018 at https://www.kommersant.ru/doc/ 1911591.

Mordyushenko, O. (2014), 'Gazprom Neft ne zaderzhalas v Afrike', accessed 16 October 2018 at https://www.kommersant.ru/doc/2400335.

Neft i kapital (2004a), 'Zalogovye auktsiony', Neft i kapital, 10, 37.

Neft i kapital (2004b), 'Yuksi, YUKOS-Sibneft', Neft i kapital, 10, 64.

Neft i kapital (2004c), 'Sibneft', Neft i kapital, 10, 24.

Neft i kapital (2004d), 'Intensifikatsiya dobychi', Neft i kapital, 10, 153.

Neft i kapital (2004e), 'ONACO', Neft i kapital, 10, 121.

Neft, gaz i fondovyy rynok (2008), 'Sibneft', accessed 15 October 2018 at http://www .ngfr.ru/library.html?sibneft.

Neftegaz (1999), 'Otets-osnovatel Gazproma', accessed 15 October 2018 at https:// magazine.neftegaz.ru/index.php?option=com content\&task=view\&id=115.

Neftegaz (2012), 'SIBUR zapustil Vyngapurovskiy GPZ, zavershiv realizatsiyu plana po pererabotke PNG', accessed 23 January 2019 at https://neftegaz.ru/news/view/ 104335-Sibur-zapustil-Vyngapurovskiy-GPZ-zavershiv-realizatsiyu-plana-po -prerabotke-PNG.

Neftegaz (2013), 'Gazprom Neft: Strategiya razvitiya do 2025 goda', accessed 23 January 2019 at https://neftegaz.ru/news/view/110240-Gazprom-neft.-Strategiya -razvitiya-do-2025-g.

Neftegazovaya vertikal (2006a), 'Perviy milliard dlya Gazproma', Neftegazovaya vertikal, 13, 42-4. 
Neftegazovaya vertikal (2006b), 'O roli lichnosti v neftedobyche', Neftegazovaya vertikal, 18, 4-6.

Neftegazovaya vertikal (2015), 'Sanktsii na puti k 100 millionam', Neftegazovaya vertikal, 2, 34-40.

Neftegazovaya vertikal (2016), 'Gazprom Neft otkazalas ot pokupki 49\% edinstvennogo vietnamskogo NPZ', accessed 16 October 2018 at http://www.ngv.ru/ news/gazprom_neft_otkazalas_ot_pokupki_49_edinstvennogo_vetnamskogo_npz_/ ?sphrase $\mathrm{id}=29245 \overline{8}$.

Neftianka (2018), 'Gazprom Neft pozvala Shell na Ayashskiy', accessed 23 January 2019 at http://neftianka.ru/gazprom-neft-pozvala-shell-na-ayashskij/.

NEWSru (2004), 'Experty schitayut pokazukhoi pretenzii nalogovikov k Sibnefti', accessed 15 October 2018 at https://www.newsru.com/finance/03mar2004/sibneft .html.

Nikolaeva, A. (2005), 'Odin za vsekh oligarchov', accessed 16 October 2018 at https:// www.vedomosti.ru/newspaper/articles/2005/09/13/odin-za-vseh-oligarhov.

Peretolchina, A., A. Fialko and A. Grechman (2010), 'Zaburitsya v Gvineyu', accessed 16 October 2018 at https://www.vedomosti.ru/newspaper/articles/2010/06/ 28/zaburitsya-v-gvineyu.

Petlevoy, V. (2017), 'Gazprom Neft zovet partnerov v Afriku', accessed 16 October 2018 at https://www.vedomosti.ru/business/articles/2017/03/29/683288-gazprom -neft.

Petlevoy, V., F. Sterkin and A. Toporkov (2018), 'Gazprom Neft sozdaet sobstvennyi rezervnyi fond', accessed 16 October 2018 at https://www.vedomosti.ru/business/ articles/2018/02/12/750608-gazprom-neft-rezervnii-fond.

Petrachkova, A. and E. Derbilova (2007), 'Ne podelili Tomskneft', accessed 15 October 2018 at https://www.vedomosti.ru/newspaper/articles/2007/07/13/ne -podelili-tomskneft.

Podobedova, L. (2015), 'Gazprom Neft poluchila rekordnuyu otsrochku po dobyche nefti na shelfe', accessed 16 October 2018 at https:/www.rbc.ru/business/15/11/ 2015/5645a9429a7947c868dcadf9.

Proskurnina, O. (2005), 'Grazhdanin Chukotki', accessed 16 October 2018 at https:// www.vedomosti.ru/newspaper/articles/2005/10/24/grazhdanin-chukotki.

Raibman, N. (2011), 'Iran lishil Gazprom Neft prava na razrabotku mestorozhdeniya Azar', accessed 16 October 2018 at https://www.vedomosti.ru/business/articles/ 2011/08/29/iran_lishil_gazmprom_neft_prava_na_razrabotku.

RBC (2005), 'Gazprom pokupaet $72.6 \%$ aktsiy Sibnefti za $\$ 13$ mlrd', accessed 24 January 2019 at https://www.rbc.ru/economics/28/09/2005/5703c2659a7947dde8e09d60.

Reznik, I. (2006a), 'Sibneft ne podkachaet', accessed 15 October 2018 at https://www .vedomosti.ru/newspaper/articles/2006/02/10/sibneft-ne-podkachaet.

Reznik, I. (2006b), 'Gazprom Neft ne uidet s birzhi', accessed 15 October 2018 at https://www.vedomosti.ru/newspaper/articles/2006/09/29/gazprom-neft-ne-ujdet-s -birzhi.

Reznik, I. (2006c), 'Intervyu: Alexander Ryazanov, president Sibnefti', accessed 15 October 2018 at https://www.vedomosti.ru/newspaper/articles/2006/02/15/intervyu -alexandr-ryazanov-prezident-sibnefti.

Reznik, I. (2006d), 'Monopoliya torguetsya', accessed 15 October 2018 at https://www .vedomosti.ru/newspaper/articles/2006/07/25/monopoliya-torguetsya.

Reznik, I. and E. Derbilova (2005a), 'Sibir vybivaet Sibneft', accessed 15 October 2018 at https://www.vedomosti.ru/newspaper/articles/2005/08/31/sibir-vybivaet-sibneft. 
Reznik, I. and E. Derbilova (2005b), 'Nachalnik nashelsya', accessed 15 October 2018 at https://www.vedomosti.ru/newspaper/articles/2005/10/19/nachalnik-nashelsya.

Reznik, I. and A. Temkin (2006), 'Sibnefti skoro ne stanet', accessed 15 October 2018 at https://www.vedomosti.ru/newspaper/articles/2006/04/03/sibnefti-skoro-ne -stanet.

Reznik, I. and A. Tutushkin (2006), 'Gazprom Neft ne pustili na MNPZ', accessed 15 October 2018 at https://www.vedomosti.ru/newspaper/articles/2006/06/23/gazprom -neft-ne-pustili-na-mnpz.

Rozhkova, M. and I. Reznik (2009), 'Khroniki 1999-2009: Skvazhina Abramovicha', accessed 15 October 2018 at https://www.vedomosti.ru/newspaper/article.shtml ?2009/07/20/205787.

Salomon Brothers (1996), Russian Oil, Vertically Integrated Companies, Volume 3 of Report on Russian Oil, March, London: Salomon Brothers.

Savushkin, S. (1998) 'Ne sliyaniye, tak pogloscheniye', Neft i kapital, 25 (8), 25-6.

Serov, M. and M. Chelpanova (2013), 'Goskompanii uekhali vo Vietnam', accessed 16 October 2018 at https://www.vedomosti.ru/newspaper/articles/2013/11/13/ goskompanii-uehali-vo-vetnam.

SeverPress (2014), 'Novy variant granits Messoyakhinskogo zakaznika utverdyat na obshchestvennykh slushaniyakh', accessed 23 January 2019 at https://sever-press .ru/2014/09/15/novyj-variant-granits-messoyakhinskogo-zakaznika-utverdyat-na -obshchestvennykh-slushaniyakh/.

Solodovnikova, A. (2013a), 'Gazprom Neft razlivaetsya po Kurdistanu', accessed 16 October 2018 at https://www.kommersant.ru/doc/2135917.

Solodovnikova, A. (2013b), 'Gazprom Neft vyshla s Kuby posukhu', accessed 16 October 2018 at https://www.kommersant.ru/doc/2279921.

Starinskaya, G. (2016), 'Gazprom Neft ne hochet na shelf', accessed 16 October 2018 at https:/www.vedomosti.ru/business/articles/2016/03/25/635063-gazprom-neft -hochet-na-shelf.

Starinskaya, G. (2018), 'Gazprom Neft voshla v troiku krupneishikh proizvoditeley nefti v Rossii', accessed 16 October 2018 at https:/www.vedomosti.ru/business/ articles/2018/02/15/751116-gazprom-neft-voshla-troiku-krupneishih.

Surzhenko, V. and I. Reznik (2006), 'Tsena pisma', accessed 15 October 2018 at https://www.vedomosti.ru/newspaper/articles/2006/07/24/cena-pisma.

TRINFICO (1996), 'Sibneft: Investigation of investment attractiveness', Internal Report by TRINFICO, Moscow.

Tutushkin, A. (2005), 'Novaya pobeda Sibnefti', accessed 15 October 2018 at https:// www.vedomosti.ru/newspaper/articles/2005/08/25/novaya-pobeda-sibnefti.

Tutushkin, A. (2006), 'Gazprom Neft zapravit Kirgiziyu', accessed 16 October 2018 at https://www.vedomosti.ru/newspaper/articles/2006/06/21/gazprom-neft-zapravit -kirgiziyu.

Tutushkin, A. (2007), 'Gazprom Neft vybiraetsya iz yamy', accessed 15 October 2018 at https://www.vedomosti.ru/newspaper/articles/2007/06/22/gazprom-neft -vybiraetsya-iz-yamy.

Tutushkin, A. (2008a), 'Gazprom Neft prishla s mirom', accessed 15 October 2018 at https://www.vedomosti.ru/newspaper/articles/2008/02/21/gazprom-neft-prishla-s -mirom.

Tutushkin, A. (2008b), 'Doshla do Serbii', accessed 16 October 2018 at https://www .vedomosti.ru/newspaper/articles/2008/12/25/doshla-do-serbii. 
Tutushkin, A. (2009a), 'Gazprom Neft uglublyaetsya v Iran', accessed 16 October 2018 at https:/www.vedomosti.ru/business/articles/2009/11/12/gazprom-neft -uglublyaetsya-v-iran.

Tutushkin, A. (2009b), 'Voshla vo vkus', accessed 16 October 2018 at https://www .vedomosti.ru/newspaper/articles/2009/04/23/voshla-vo-vkus.

Tutushkin, A. and I. Vasilev (2010), 'Prishla v Kazakhstan', accessed 16 October 2018 at https://www.vedomosti.ru/newspaper/articles/2010/08/05/prishla-v-kazahstan.

Vakulenko, S. (2018), 'Gazprom Neft: Osnovnye idei strategicheskogo razvitiya', accessed 8 February 2019 at https://www.gazprom-neft.ru/press-center/lib/1642212/ ?sphrase id $=5595871$.

Vinogradov, I. (1998), 'Elf tochno otkazalas ot Rossii', accessed 24 January 2019 at https://www.kommersant.ru/doc/204019.

Zanina, A. (2011), 'Ya diplom ne pisal. Vsyo ostalnoe delal', accessed 15 October 2018 at https://www.kommersant.ru/doc/1807636. 